\title{
The Physicochemical Profile Of Feun Kase (Thevetia Peruviana) Oil As A New Feedstock For Renewable Energy
}

\author{
Jefry Presson ${ }^{\mathrm{a}}$, Yohana Ivana Kedang ${ }^{\mathrm{a}}$ dan Suwari ${ }^{\mathrm{b}}$ \\ ${ }^{a}$ Fakultas Pertanian, Universitas Timor, Kefamenanu, TTU - NTT, Indonesia, email: pressontimor@gmail.com \\ ${ }^{a}$ Fakultas Pertanian, Universitas Timor, Kefamenanu, TTU - NTT, Indonesia, email: ivanakedang@gmail.com \\ ${ }^{b}$ Fakultas Sains dan Teknik, Universitas Nusa Cendana, Kefamenanu, Kupang - NTT, Indonesia, email: suwari_2021@gmail.com
}

\section{Article Info}

\section{Article history:}

Received 16 Desember 2020

Received in revised form 06 Januari 202

Accepted 21 Januari 2021

\section{DOI:}

https://doi.org/10.32938/sc.v6i01.1238

Keywords:

Renewable energy

Biodiesel

Thevetia peruviana

Feun Kase

Dry land

\section{Introduction}

Energy supply in the future is still a popular issue. The evidence could be clearly seen in the development of industrial and technology sectors, economic growth and population growth. Currently, biodiesel is still a popular renewable energy because of its benign and easy to obtain. In addition, using biodiesel could reduce COxand SOx gas emissions (Verma and Sharma, 2015). In the transesterification process, biodiesel is produced from vegetable oil. This oil can be obtained from soybean, canola, palm, corn, coconut, and many more. The United States Department of Energy states that, in 2018 there were 1,857 million gallons of biodiesel produced from edible oil. Soybean oil, corn oil and soybean oil were highest in sales, respectively 7,542; 2,084; and 1.197 million Pound (Energy, 2019).

The raw material for biodiesel which competes with the food sector is still being a controversy (Mekhilef, Siga and Saidur, 2011). The selling price of biodiesel is too high, and the fluctuation in raw material (food) price causes biodiesel to be unpopular. Therefore, the biodiesel sector really needs non-food raw materials (Ajanovic, 2011; Tokgozet al., 2012). Feun Kase (Thevetia peruviana) seeds contain quite high oil, namely $63 \%$ (A Ibiyemi et al., 2002). However, this oil contains toxic cardiac glycosides such as thevetin A, thevetin B, neriifolin, and ruvoside (Singh et al., 2012). Therefore, this oil is classified as non-edible oil and has not been utilized for biodiesel production. However, Feun Kase (Thevetia peruviana) is very abundant in Indonesia and has not received attention to be developed as a source of biodiesel. This research is focused on 10 tests of physico-chemical parameters according to SNI 7182: 2015. In addition, the fatty acid content of Feun Kase oil is shown by GCMS data.

\section{Method}

Materials

The materials used in this study included Feun Kase seeds, ethanol, $\mathrm{KOH}, \mathrm{NaOH}, \mathrm{HCl}, \mathrm{Na}_{2} \mathrm{~S}_{2} \mathrm{O}_{3}, \mathrm{H}_{2} \mathrm{C}_{2} \mathrm{O}_{4}$, petroleum ether, pp indicator, chloroform, iodine, starch solution, glacial acetic acid, bromine, and $\mathrm{KI}$ solution. All obtained from Merck Indonesia.

\section{Sampling and preparation}

Samples of Feun Kase seeds were taken from East Nusa Tenggara Province (Indonesia). Sample preparation was carried out at the Laboratory of the Faculty of Agriculture, University of Timor and the Laboratory of Chemistry, Faculty of Science and Engineering, University of Nusa Cendana. The Feun Kase meal was blended and dried in an oven at $60^{\circ} \mathrm{C}$ with particular time variations. The dried Feun Kase is stored in a closed container.

\section{Oil Isolation}

Oil isolation was carried out by pressing (B1) and by means of soxhlet (B2) using petroleum ether which lasted for 4 hours at $60^{\circ} \mathrm{C}$.

\section{Moisture Content}

This test was carried out by heating the oil in an oven at $105^{\circ} \mathrm{C}$ for 3 hours. Weight lost was calculated as moisture content (\%).

$$
\begin{gathered}
\text { Moisture content }(\%)=\frac{a-b}{a} \times 100 \% \\
\mathrm{a}=\text { sample weight before oven } \\
\mathrm{b}=\text { sample weight after oven }
\end{gathered}
$$

\section{Acid Number}

Two grams of sample was added with $10 \mathrm{~mL} \mathrm{EtOH}$ in an Erlenmeyer and shaken for 10 minutes until the oil dissolves in the solvent. After dissolving, 1 drop of $1 \%$ pp indicator was added and titrated with $0.1 \mathrm{~N} \mathrm{KOH}$ until the pink color did not disappear for 30 seconds. The volume of $\mathrm{KOH}$ used was recorded. The procedure was carried out for B1 and B2 twice.

$$
\text { Acid Number }=\frac{\mathrm{V}_{\mathrm{KOH}} \times \mathrm{N}_{\mathrm{KOH}} \times 56.11}{\text { sample weight }}
$$

\section{Saponification Number}

The oil was refluxed with $\mathrm{KOH} 0.5 \mathrm{~N}$, then titrated with $0.5 \mathrm{~N} \mathrm{HCl}$. The saponification number was calculated according to the following equation:

Iodine Value

$$
B P=\frac{\left(\mathrm{V}_{\mathrm{HCl}} \text { blanko }-\mathrm{V}_{\mathrm{HCl}} \text { sample }\right) \times \mathrm{N} \mathrm{KOH} \times 56,11}{\text { oil weight }(\mathrm{g})}
$$

This test was performed using Hanus reagent and then titrated with $\mathrm{Na}_{2} \mathrm{~S}_{2} \mathrm{O}_{3}$. The calculation of iodine value is carried out according to the following equation:

$$
\begin{aligned}
& \text { Iod value }=\frac{(\mathrm{B}-S) \times N \times 12,69}{G} \\
& \text { Information: } \\
& \mathrm{B}: \mathrm{mL} \mathrm{Na} \mathrm{S}_{2} \mathrm{O}_{3} \text { for blank titration } \\
& \mathrm{S}: \mathrm{mL} \mathrm{Na} \mathrm{S}_{2} \mathrm{O}_{3} \text { for sample titration } \\
& \mathrm{N} \text { : normality of the } \mathrm{Na}_{2} \mathrm{~S}_{2} \mathrm{O}_{3} \text { solution } \\
& \mathrm{G} \text { : sample weight }
\end{aligned}
$$

Density

This test refered to SNI 7182: 2015 using pycnometer and was calculated using the formula below.

$$
\begin{aligned}
& \quad \mathrm{D}=\frac{(\mathrm{A}+\text { sample })-(\mathrm{A})}{\text { Volume sample }} \\
& \text { Information : } \\
& \mathrm{D}=\text { Density } \\
& \mathrm{A}=\text { Pycnometer weight }
\end{aligned}
$$

Viscocity

This test was done by calculating the oil flow time in the Otswald viscometer and then calculating it by the equation below.

$$
\eta=\eta_{0} \frac{t \cdot \rho}{t_{0} \cdot \rho_{0}}
$$

\section{Cloud Point}

Oil was put into the test tube $(30 \mathrm{~mm}$ in diameter) and covered with a rubber cover that has been attached with a thermometer. Then put in a container filled with water and ice cubes. Pay attention to the temperature on the thermometer and the bottom of the tube. When crystals (cloud) begin to appear, the temperature in this state was recorded as a cloud point.

\section{Cetane Number}

Cetane numberwere determined by the following calculations (GuilLaynez, Guil-Guerrero and Guil-Laynez, 2019):

$$
\begin{aligned}
& \mathrm{CN}=46,3+5.458 / \mathrm{SN}-0,225 \times \mathrm{IV} \\
& \text { Information: } \\
& \mathrm{CN}=\text { Cetane Number } \\
& \mathrm{SN}=\text { Saponification Number } \\
& \mathrm{IV}=\text { Iodine Value }
\end{aligned}
$$

Flash Point

The flash point in this study was carried out by the Pensky Martens. This test was carried out at the Laboratory of Petroleum Gas and Coal, Department of Chemical Engineering, Gadjah Mada University. 


\section{Analysis of Fatty Acid}

Screening was carried out using GCMS at the Chemical Laboratory of the Department of Chemistry, Gadjah Mada University. The state of the GCMS is as follows: GCMS brand - QP2010S SHIMADZU; AGILENTJ \% W DB-1 column; column length $30 \mathrm{~m}$; diameter $0.25 \mathrm{~mm}$; ionizing EI $70 \mathrm{Ev}$; pressure $12 \mathrm{kPa}$; and a flow rate of $0.54 \mathrm{~mL} / \mathrm{min}$. Before the analysis, the oil was transesterified so that could be analyzed on GCMS

\section{Results and Discussion}

\section{Sample Preparation}

Removing water content in Feun Kase oil is an important step to obtain Feun Kase oil which is safe for storage. The optimum drying time for Feun Kase has been determined by comparing the amount of weight lost in test plate (C1-C6) at $60^{\circ} \mathrm{C}$. The best result is 4 hours with $12.27 \%$ weight loss, shown by the graph in Figure 1.

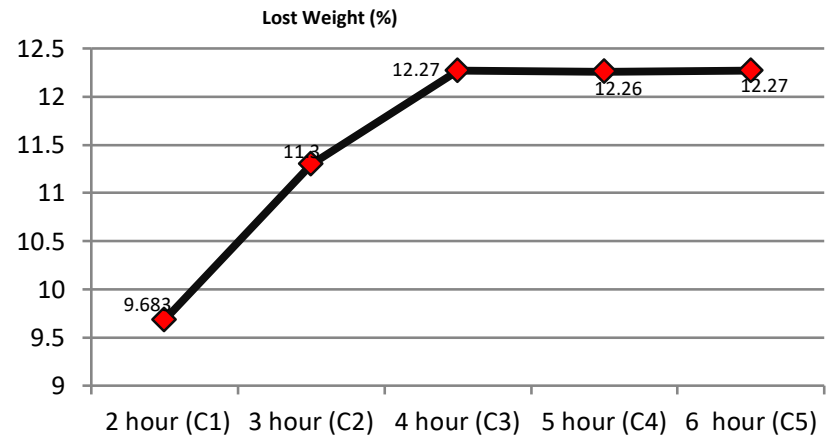

Figure 1. Drying time of test plate

\section{Oil Isolation}

The isolation in 2 different ways resulted in a very significant yield calculation. Through the press method (B1), the yield was $25.58 \%$, while in the sox let method, the yield was $66.32 \%$. This means that the soxhlet method is the best way for extracting the oil out from Feun Kase. However, it requires additional treatment such as distillation to separate the solvent from the oil.

Rendement (\%)

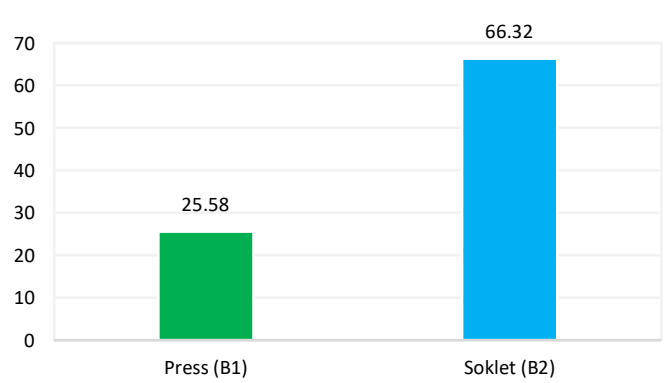

Figure 2. The Comparison of oil isolation rendement

\section{Moisture Content}

The Moisture content of Feun Kase oil is lower than the SNI standard. The moisture content of the pressed and soxhlet oil were $0.003 \%$ and $0.004 \%$, respectively. The results are shown in the graph in Figure 2. The results indicated that the water content of Feun Kase oil is in accordance with SNI standards.

\section{Water Content $(\%)$}

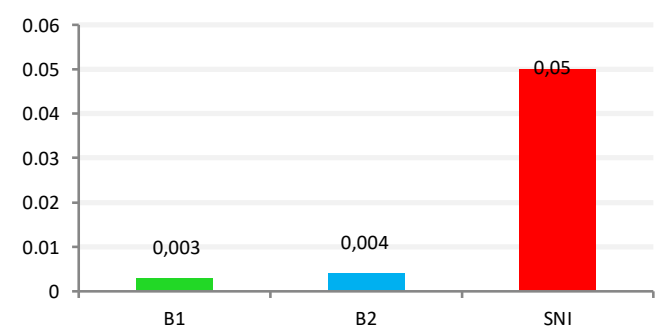

Figure 3. Moisture Content of B1 and B2

\section{Acid Number}

The amount of $\mathrm{KOH}$ neutralizing the free fatty acids in $\mathrm{B} 1$ is $1.94 \mathrm{mg}$ $\mathrm{KOH} / \mathrm{g}$ sample, while in $\mathrm{B} 2$ is $1.38 \mathrm{mg} \mathrm{KOH} / \mathrm{g}$ sample.

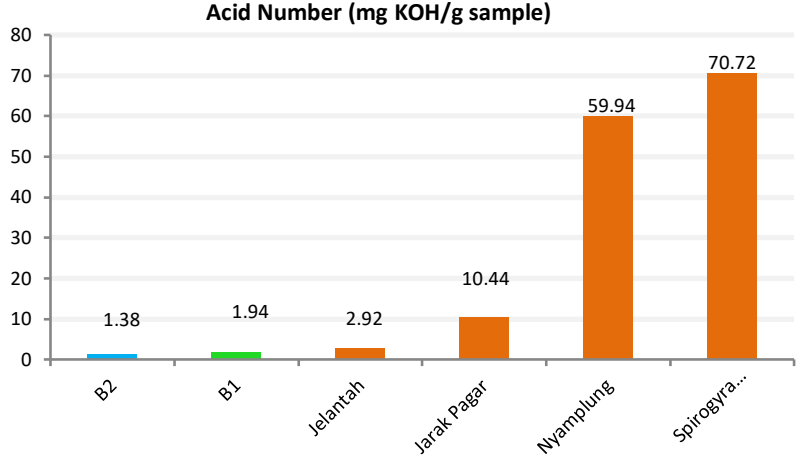

Figure 4. The Comparison of Acid Number of Various Oil.

When compared with the acid number of Nyamplung oil, which is 59.94 mg KOH / g sample (E Atabaniet al., 2011), the acid number of Feun Kase oil gives a better number because it is closest to SNI. Data regarding this acid number is very important in choosing method when this oil is converted into biodiesel. For example, if the acid number is too high, it will produce a lot of soap in the transesterification process.

\section{Saponification Number}

The amount of $\mathrm{KOH}$ for B1 was $165.65 \mathrm{mg} \mathrm{KOH} / \mathrm{g}$ sample, while B2 was $166.38 \mathrm{mg} \mathrm{KOH} \mathrm{/} \mathrm{g}$ sample. It can be seen that the saponification number of B1 and B2 do not differ much. This means that the press or soxhlet method does not affect the saponification number.

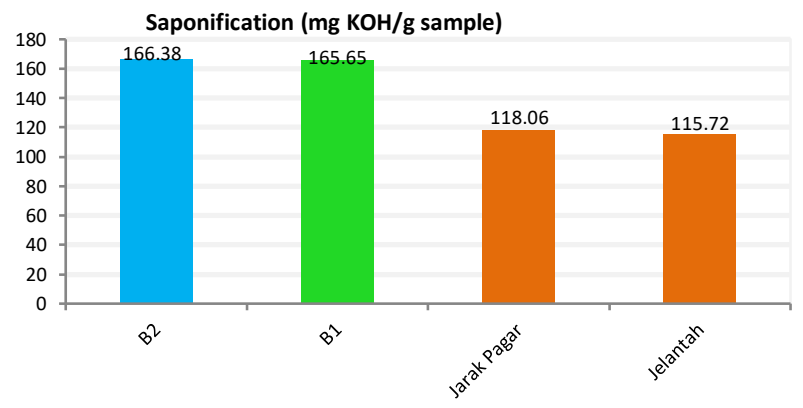

Figure 5. The Comparison of saponification number of Various Oil.

\section{Iodine Value}

The iodine valuefor B1 from this study was $137.44 \mathrm{mg} \mathrm{I}_{2} / 100 \mathrm{~g}$ sample, while the B2 was $126.87 \mathrm{mg} \mathrm{I}_{2} / 100 \mathrm{~g}$ sample. This number shows the number of double bonds in the fatty acid which can react with iodine. In accordance with SNI, the calculated number do not meet the standard, namely a maximum of $115 \mathrm{mg} \mathrm{I}_{2} / 100 \mathrm{~g}$ of sample.

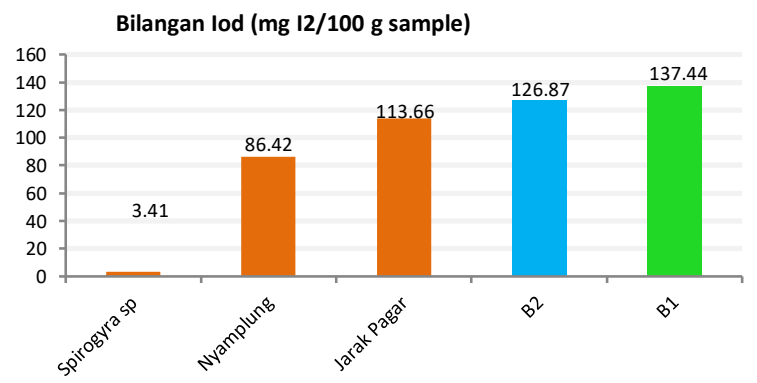

Figure 6. The Comparison of Iod Number of Various Oil

From the above comparison, it can be seen that Feun Kase oil has the highest iodine value among other oils. The number of unsaturated fatty compounds in the oil also makes it easier for these compounds to react with oxygen.

\section{Density}

The density of B1 calculated from the results of this study is $884 \mathrm{Kg} /$ $\mathrm{m}^{3}$, while that of B2 is $855 \mathrm{Kg} / \mathrm{m}^{3}$. It can be seen that the density of Feun Kase meets the standard by SNI, namely in the range $850-890 \mathrm{Kg} / \mathrm{m}^{3}$. 
Density $(\mathrm{Kg} / \mathrm{m} 3)$

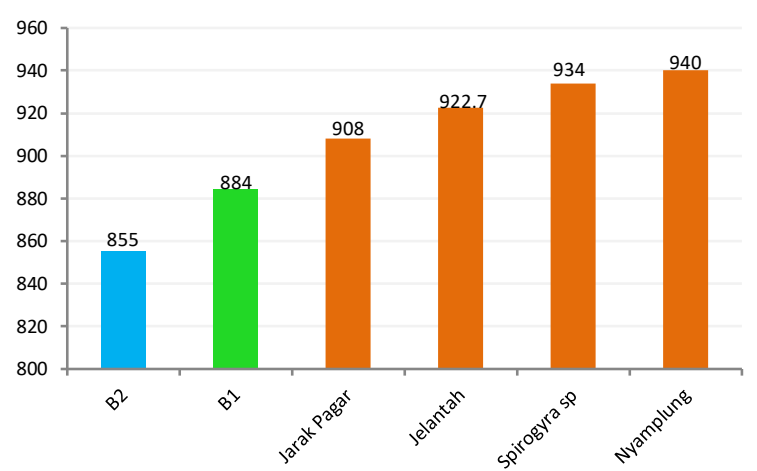

Figure 7. The Comparison of Density of Various Oil.

If the density value between B1 and B2 is related to the acid number, it can be seen that B1 with a higher density has a higher acid number compared to B2. It is also reported by Madhu Agarwal that castor oil (B) with a high free fatty acid content, has a density of $920 \mathrm{Kg} / \mathrm{m}^{3}$. Meanwhile, castor oil (A) with a low free fatty acid content has a lower density, namely $880 \mathrm{Kg} / \mathrm{m}^{3}$ (Agarwalet al., 2012). The low content of fatty acids in Feun Kase oil causes a better density than jarak oil.

\section{Viscosity}

The viscosity of B1 calculated from the results of this study is 22.25 $\mathrm{mm}^{2} / \mathrm{s}$, while that of B2 is $19.91 \mathrm{~mm}^{2} / \mathrm{s}$. From this data, it can be seen that the viscosity of Feun Kase has not met the standards by SNI, namely in the range $2.3-6.0 \mathrm{~mm}^{2} / \mathrm{s}$. Crude palm oil is reported to have a viscosity of 37.5 $\mathrm{mm}^{2} / \mathrm{s}$ at $40^{\circ} \mathrm{C}$ (Rotimi, 2016). Viscosity is a very important parameter when this oil is applied to diesel engines. If the viscosity is too high, it is difficult to burn the oil in a diesel engine.

\section{Viscosity (mm2/s)}

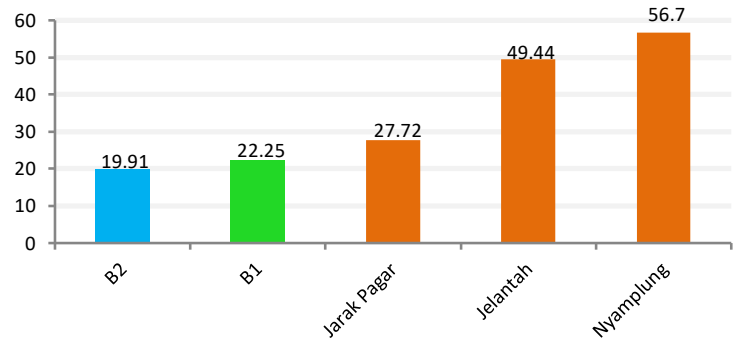

Figure 8. Comparison of Viscosity of Various Oils

\section{Cloud Point}

The cloud points of $\mathrm{B} 1$ and $\mathrm{B} 2$ were the same, which is at $2{ }^{\circ} \mathrm{C}$. Thus, the cloud point of Feun Kase in this study meets the SNI standard, namely a maximum of $18^{\circ} \mathrm{C}$. If the cloud point is too high, then the oil can easily change to solid phase according to the local air temperature, so this is very disturbing during storage and application to the engine. Considering that Indonesia has areas with varying temperatures, the lower the cloud point the better, because this oil can be used in anywhere.

\section{Cetane Number}

The calculation results show that the cetane number B1 is 48.32 while B2 is 50.55. SNI provides a standard cetane number of at least 51. When compared with SNI, both B1 and B2 have not entered the criteria for good biodiesel, although B2 with a cetane number of 50.55 is almost close to the standard. If you look at the formula given by AOCS (Guil-Laynez, GuilGuerrero and Guil-Laynez, 2019), it can be concluded that the low cetane number in Feun Kase oil is caused by the high iodine number. In other words, high levels of unsaturated fatty acids lead to low cetane numbers.

\section{Flash Point}

Flash points B1 and B2 were not detected by the Pensky Martens Close Cup (PMCC) device, so it was followed by a Cleveland Open Cup (COC) with a flash point of $324{ }^{\circ} \mathrm{C}$ for B1 and $322.5^{\circ} \mathrm{C}$ for B2. Methyl esters from palm oil are reported to have a flash point of $170{ }^{\circ} \mathrm{C}$ (Ayetor, Sunnu and Parbey, 2015). The flash point of Feun Kase oil does not meet the standards by SNI.

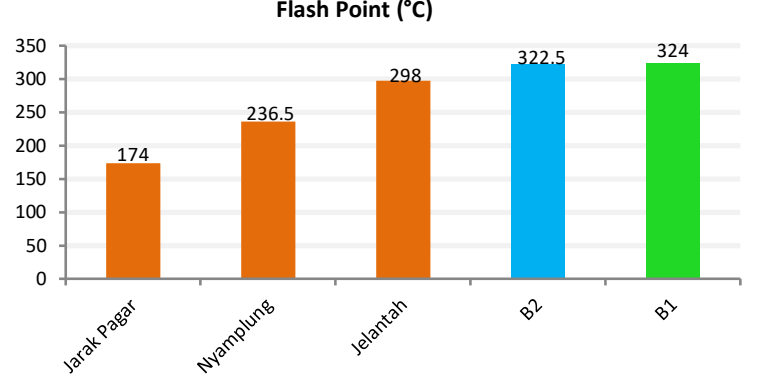

Figure 9. Comparison of flash points of various oils

From the above comparison, it can be seen that Feun Kase occupies a very high flash point. This is very unfortunate if directly applied to diesel engines. Combustion will be very slow because it takes a long time to reach that temperature. As a comparison, Madhu Agarwal in 2011 stated that the transesterified castor oil has a flash point of $174{ }^{\circ} \mathrm{C}$ (Agarwalet al., 2012). Feun Kase oil may provide a decent flash point number if it is continued with a transesterification method such as that of Agarwal.

\section{Fatty Acid Content}

It should be noted that this Feun Kase oil is transesterified first before being put on GCMS. The decrease in viscosity of the transesterified oil really helps the analysis process at GCMS. Therefore, the molecular weight of the spectra data below includes methyl from the transesterification results. At the retention time of 36.301 with an abundance of $26.73 \%$, the mass spectra data showed that the molecular weight was at the peak m / z $270\left[\mathrm{M}^{+}\right]$. If you subtract the weight of $\mathrm{CH}_{2}$ (methyl from the transesterification result), then a compound with a molecular weight of $256 \mathrm{~g} / \mathrm{mol}$ is obtained. This compound is hexadecanoic acid or better known as palmitic acid with the molecular formula $\mathrm{C}_{16} \mathrm{H}_{32} \mathrm{O}_{2}$ (figure 9 and 10). Palmitic acid is also found in palm oil with a content of $39.1 \%$ (Anguebes et al., 2016).

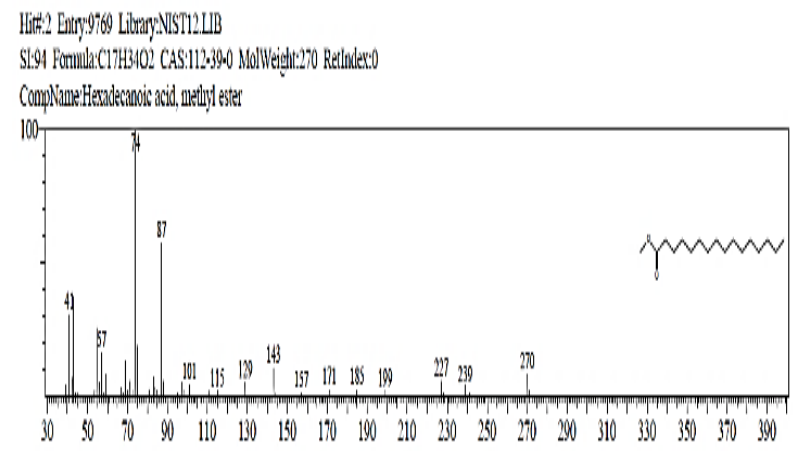

Figure 9. GCMS mass spectra at retention time of 36.301 for palmitic acid

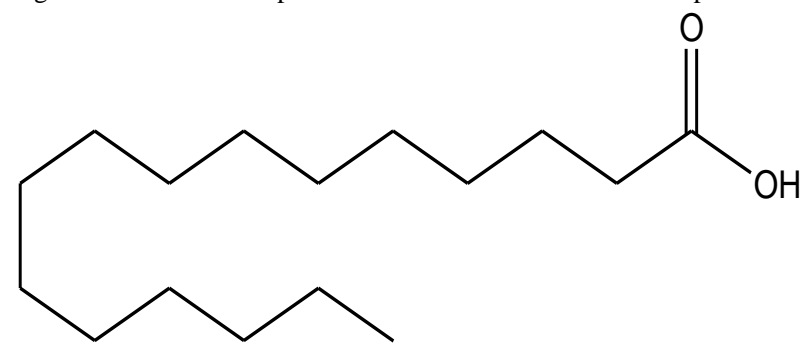

Figure 10. Structure of palmitic acid

At the retention time of 39,665 with an abundance of $12.41 \%, 9,12$ octadecadinoate was detected with the molecular formula $\mathrm{C}_{18} \mathrm{H}_{32} \mathrm{O}_{2}$ where there are 2 double bonds in the alkyl chain (figure 11 and 12). This compound is also called linoleic acid which is the largest component in corn oil (Niet al., 2016; Veljkovićet al., 2018), and flower oil (Zheljazkovet al., 2009). 
Hitt?: Entry.41849 Lilwrar:NST62.LBB

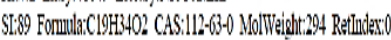

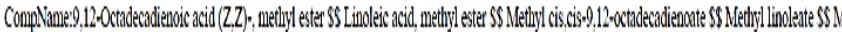

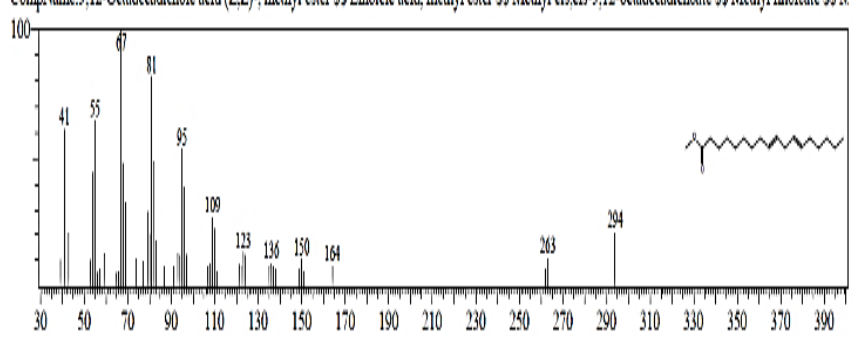

Figure 11. GCMS mass spectra at retention time of 39.665 for linoleic acid

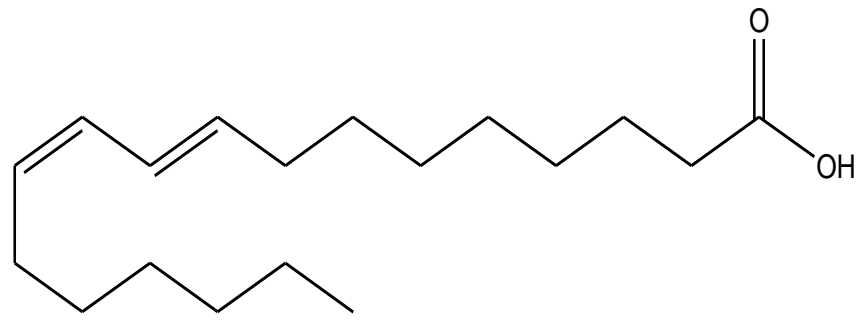

Figure 12. Structure of linoleic acid

At the retention time of 39.764 with an abundance of $55.83 \%$, 9 octadecanoic or better known as oleic acid with the molecular formula $\mathrm{C}_{18} \mathrm{H}_{34} \mathrm{O}_{2}$ was also detected (figure 13 and 14). Oleic acid is also very abundant in olive oil at $69.58 \%$ (Dehghan, Golmakani and Hosseini, 2019).

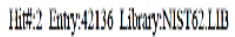

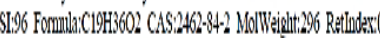

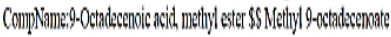

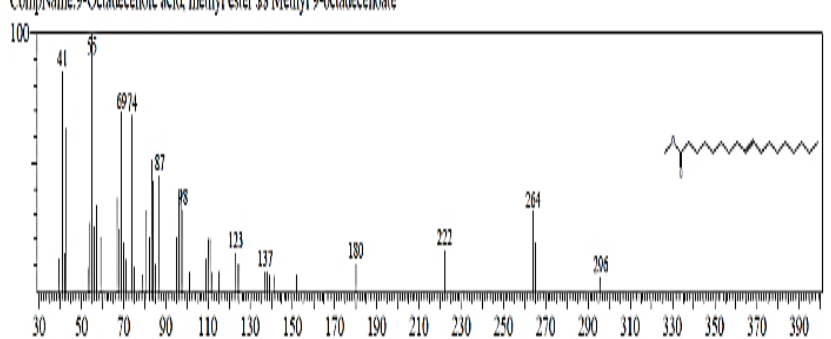

Figure 13. GCMS mass spectra at retention time of 39.764 for oleic acid

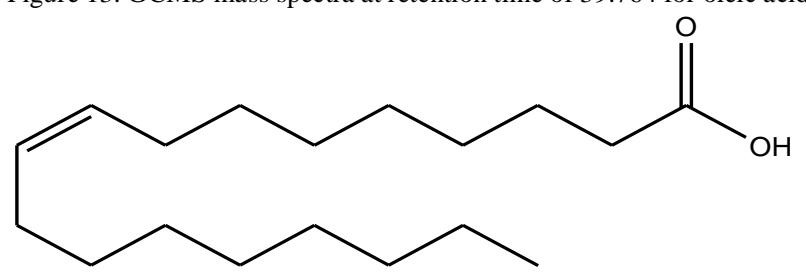

Gambar 14. Structure ofoleic acid

At the retention time of 40.262 with an abundance of $5.03 \%$, the mass spectra data showed that the molecular weight was at the peak $\mathrm{m} / \mathrm{z} 298\left[\mathrm{M}^{+}\right]$. If the molecular weight of $\mathrm{CH}_{2}$ (transesterified methyl) is subtracted, a compound with a molecular weight of $284 \mathrm{~g} / \mathrm{mol}$ is obtained (figure 15 and 16). This compound is octadecanoic acid or also known as stearic acid, which is known as a raw material for making soaps, cosmetics, candles, plastics and other household uses (Kumar, Sharma and Upadhyaya, 2016).

\section{Hitrit Entry:10481 Libany:NSTILIIB}

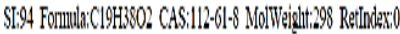

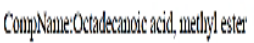

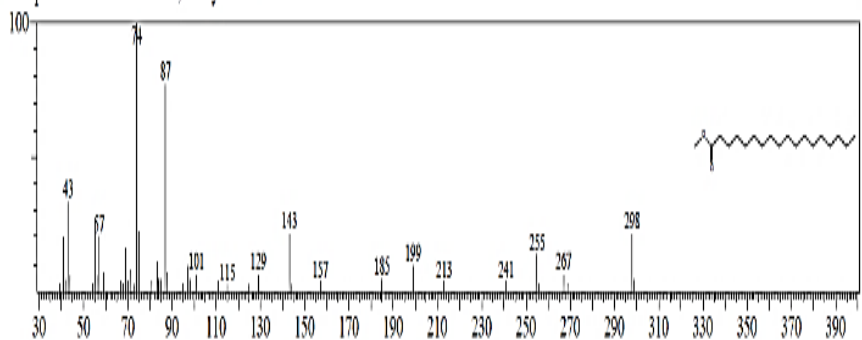

Figure 15. GCMS mass spectra at retention time of 40,262 for stearic acid

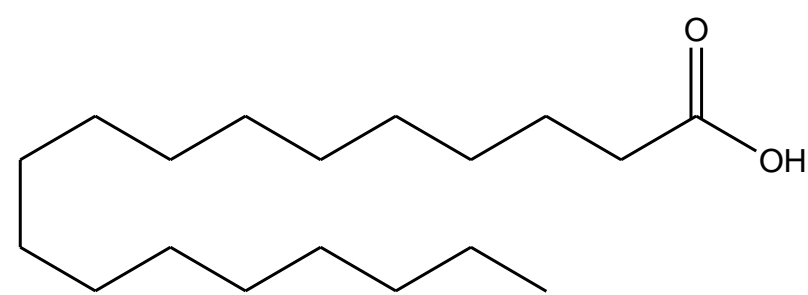

Figure 16. Structure of stearic acid

\section{Conclusion}

Oil isolation by means of soxhlet gave a better yield than press method. Soxhlet (B2) gave $66.32 \%$ and press (B1) gave $25.58 \%$ yield.Physico-chemical properties of Feun Kase (Thevetia peruviana) oil in this study were shown by the moisture content of $0.003 \%$ (B1) and $0.004 \%$ (B2), the acid number 1.94 $\mathrm{mg} \mathrm{KOH} / \mathrm{g}$ sample (B1) and $1.38 \mathrm{mg} \mathrm{KOH} \mathrm{/} \mathrm{g} \mathrm{sample} \mathrm{(B2),} \mathrm{lathering} \mathrm{number}$ $165.65 \mathrm{mg} \mathrm{KOH} / \mathrm{g}$ sample (B1) and $166.38 \mathrm{mg} \mathrm{KOH} / \mathrm{g}$ sample (B2), the ester content is $98.82 \%$ (B1) and $99.16 \%$ (B2), iodine value $137.44 \mathrm{mg} \mathrm{I} 2 / 100$ g sample (B1) and $126.87 \mathrm{mg} \mathrm{I2} \mathrm{/} 100 \mathrm{~g}$ sample (B2), density $884 \mathrm{Kg} / \mathrm{m} 3$ (B1) and $855 \mathrm{Kg} / \mathrm{m} 3$ (B2), viscosity $22.52 \mathrm{~mm} 2 / \mathrm{s}$ (B1) and $19.91 \mathrm{~mm} 2 / \mathrm{s}$ (B2), cetane numbers 48.32 (B1) and 50.55 (B2), flash points $324{ }^{\circ} \mathrm{C}$ (B1) and 322.5 ${ }^{\circ} \mathrm{C}$ (B2), and cloud point of $2{ }^{\circ} \mathrm{C}$ both B1 (press) and B2 (soxhlet). The fatty acids content in Feun Kase oil are hexadecanoic acid (palmitic acid), 9,12octadecadinoic acid (linoleic acid), 9-octadecanoic acid (oleic acid), and octadecanoic acid (stearic acid).The physico-chemical properties of Feun Kase oil that meet the standards according to SNI 7182: 2015 are water content, ester content, density and cloud point. Meanwhile, those that do not meet SNI standards are the acid number, iodine value, viscosity, cetane number and flash point. From some of the physico-chemical properties of Feun Kase oil and its fatty acid content, it can be concluded that Feun Kase oil can be used as a raw material for making

\section{References}

A Ibiyemi, S., Fadipe, V., O Akinremi, O., Bako, S. (2002) Variation in Oil Composition of Thevetia Peruviana Juss 'Yellow Oleander' Fruit Seeds, Journal of Applied Sciences and Environmental Management. doi: 10.4314/jasem.v6i2.17178.

Agarwal, M., Singh, K., Upadhyaya, S., Chaurasia, S. (2012) Potential vegetable oils of Indian origin as biodiesel feedstock - An experimental study, Journal of Scientific and Industrial Research.

Ajanovic, A. (2011) 'Biofuels versus food production: Does biofuels production increase food prices?', Energy. Elsevier, 36(4), pp. 2070-2076.

Anguebes, F.,Córdova-Quiroz, A., Griselda, C., Aguilar, C., Castillo-Martínez, G., Cerón-Bretón, R., Ruíz-Marín, A. Montalvo, C. (2016) 'Optimization of Biodiesel Production from African Crude Palm Oil ( Elaeis guineensis Jacq) with High Concentration of Free Fatty Acids by a Two-Step Transesterification Process', Open Journal of Ecology, 06, pp. 13-21. doi: 10.4236/oje.2016.61002.

Ayetor, G., Sunnu, A. and Parbey, J. (2015) 'Effect of biodiesel production parameters on viscosity and yield of methyl esters: Jatropha curcas, Elaeis guineensis and Cocos nucifera', Alexandria Engineering Journal, 54. doi: 10.1016/j.aej.2015.09.011.

Dehghan, L., Golmakani, M.-T. and Hosseini, S. M. H. (2019) 'Optimization of microwave-assisted accelerated transesterification of inedible olive oil for biodiesel production', Renewable Energy, 138, pp. 915-922. doi: https://doi.org/10.1016/j.renene.2019.02.017

E Atabani, A. Silitonga, A., Mahlia, T.M.I., Masjuki, H.H., Badruddin, I. (2011) Calophyllum inophyllum L. as a potential feedstock for biodiesel production.

Energy, U. S. D.(2019) Monthly Biodiesel Production Report. Washington DC: U.S. Energy Information Administration.

Guil-Laynez, J. L., Guil-Guerrero, J. L. and Guil-Laynez, Á. (2019) 'Bioprospecting for seed oils in tropical areas for biodiesel production', Industrial Crops and Products, 128, pp. 504-511. doi: https://doi.org/10.1016/j.indcrop.2018.11.044.

Kumar, A., Sharma, A. and Upadhyaya, K. C. (2016) 'Vegetable Oil: Nutritional and Industrial Perspective', Current genomics. Bentham Science Publishers, 17(3), pp. 230-240. doi: $10.2174 / 1389202917666160202220107$.

Mekhilef, S., Siga, S. and Saidur, R. (2011) 'A review on palm oil biodiesel as a source of renewable fuel', Renewable and Sustainable Energy Reviews, 15, pp. 1937-1949. doi: 10.1016/j.rser.2010.12.012.

Ni, S., Zhao, W., Zhang, Y., Gasmalla, M.A.A., Yang, R. (2016) 'Efficient and eco-friendly extraction of corn germ oil using aqueous ethanol solution assisted by steam explosion', Journal of food science and technology. 2016/04/21. Springer India, 53(4), pp. 2108-2116. doi: 10.1007/s13197-016-2189-9.

Rotimi, D. (2016) 'Effect of the temperature on dynamic viscosity, density and flow rateof some vegetable oils', Journal of Scientific Research in Engineering \& Technology, 1, pp. 14-24.

Singh, K., Agrawal, K.K., Mishra, V., Uddin, S.M., Shukla, A. (2012) A 
Review on Thevetia peruviana, International Research Journal of Pharmacy.

Tokgoz, S., Zhang, W., Msangi, S., Bhandary, P. (2012) 'Biofuels and the Future of Food: Competition and Complementarities', Agriculture, 2, pp. 414-435. doi: 10.3390/agriculture2040414.

Veljković, V. B.,Biberdžić, M. O., Banković-Ilić, I. B., Djalović, I. G., Tasić, M. B., Nježić, Z.B., Stamenković, O. S. (2018) 'Biodiesel production from corn oil: A review', Renewable and Sustainable Energy Reviews, 91, pp. 531-548. doi: https://doi.org/10.1016/j.rser.2018.04.024.

Verma, P. and Sharma, M. (2015) 'Performance and Emission Characteristics of Biodiesel Fuelled Diesel Engines', International Journal of Renewable Energy Research, 5.

Zheljazkov, V. D., Vick, B.A., Baldwin, B.S., Buehring, N., Astatkie, T., Johnson, B. (2009) 'Oil Content and Saturated Fatty Acids in Sunflower as a Function of Planting Date, Nitrogen Rate, and Hybrid', Agronomy Journal. Madison, WI: American Society of Agronomy, 101, pp. 1003-1011. doi: 10.2134/agronj2009.0011. 